\title{
CLARA CELL PROTEIN CC16 AS A BIOLOGICAL MARKER OF LUNG INJURY AMONG QUARRY WORKERS EXPOSED TO PM2.5
}

\author{
Gaballah I.F. and Rashed L.A.* \\ FROM \\ Department of Occupational Medicine and Environmental Diseases, \\ *Department of Biochemistry,Faculty of Medicine, \\ Cairo University
}

\begin{abstract}
Objective: evaluation of the use of Clara cell protein (CC16) level in serum as an early indicator of the adverse respiratory health effects of particulate matter (PM2.5) exposure.

Methods: Detailed assessment questionnaire was used for interviewing 54 individuals divided into workers exposed to particulates in the atmosphere of stone quarries and a control group. The studied population was subjected to clinical examination and pulmonary function testing in order to diagnose airway diseases and lung irritation. Laboratory investigations were done in the form of Clara cell protein and immunoglobul in A (IgA) estimation in serum using the immunoassay technique.

Results: According to the thorough occupational history and clinical examination, respiratory system affection was detected among the exposed population in the form of frequent asthmatic attacks, chronic bronchitis and chronic obstructive pulmonary disease. Pulmonary function tests demonstrated marked decrease in the expiratory flow rate $25-75 \%$ ( $F E F-25-75 \%$ ) suggesting irritation and affection of the small airways correlating to duration of exposure more than smoking index. Estimation of the
\end{abstract}


pneumoprotein $\mathrm{CC} 16$ which is produced by the epithelial cells in terminal bronchioles revealed marked elevation in serum of exposed group $(149.61 \pm 22.64 \mathrm{pg} / \mathrm{mi})$ than among the control group (107.08 $\pm 12.18 \mathrm{pg} / \mathrm{ml})$. Similarly, the humoral immune defense involving the secretory immunoglobulin A ( $\lg \mathrm{A})$ predominant in mucosal secretions was markedly elevated among the exposed than the control groups with mean values of $372.41 \pm 232.87 \mathrm{IU} / \mathrm{ml}$ and $143.76 \pm 83.531 \mathrm{U} / \mathrm{ml}$, respectively. The serurn CC 16 and IgA were both significantly negatively correlated with flow rates.Worth-mentioning, is the increased CC 16 serum levels with ageing which influences the functionality of the lungs and immune systern as evidenced by the decline in lung volumes, lung capacity and flow rates and by decreased IgA in serum.

Conclusion: The results suggest that damage of Clara cells in the small airways and the increased epithelial barrier permeability are ultimate consequences of exposure to particulates in air at the workplace. Accordingly, the elevated serum CC16 as a result of increased diffusion of this type of pneumoprotein into the circulation might be used as an early non-invasive biological indicator for lung affection.

Aim of the Work: This study was designed to investigate the cellular and humoral defense mechanisms of the respiratory tract in workers exposed to particulate air pollution in quarries in an attempt to evaluate the importance of using CC16 as a biologic marker for respiratory injury in comparison to pulmonary function tests.

Key words: ambient particulate air pollution, pneumoproteins, Clara cell protein, CC.16, Immunoglobulin A, quarrying, pulmonaryfunction tests.

\section{Introduction}

By its nature, quarrying has the potential to create dust and particulate matter (PM) air pollution (1). In fact, particulate matter air pollution consists of complex and varying mixtures of particles suspended in the air. Of greatest concern to public health are the particles small enough to be inhaled into the deepest parts of the lung. These small particles are known as PM 10 (less than 10 microns in diameter) and even finer particles are known as PN12.5 (less than 2.5 microns in diameter) ${ }^{(2)}$. Accordingly, a large number of quarry workers die a slow death as a result of breaking stone, crushing it and breathing it in as dust (1).

This ambient particulate air pollution has been associated with adverse respiratory health (3) effects in several studies. Chronic obstructive pulmonary disease (COPD) is the major cause of morbidity and mortality among respiratory diseases. This disorder is characterized functionally 
by (4) expiratory airflow limitation that is slowly progressive and mainly irreversible . Changes in lung function, reporting of symptoms, hospital admissions or mortality have usually been used as indicators of respiratory disease (5) without indication to the presence of biomarkers for lung damage. The mechanisms of adverse effects are still largely unknown. However, inflammatory processes are suspected to play a key role in the pathologic mechanisms starting from deposition of particles to the exacerbation of respiratory diseases ${ }^{(6)}$.

The defense mechanisms of the respiratory tract involve both cellular and humoral immune components ${ }^{(7)}$. As for the cellular immune defense, prominent ultrastructural characteristics of nonciliated bronchiolar (Clara) cells included an abundance of smooth endoplasmic reticulum and secretory granules ${ }^{(8)}$. Analysis of these Clara cells clearly indicated that they synthesize proteinaceous material, Clara cell protein (CC 16), to be secreted from the apical surface into the airway lumen. The nature of Clara cell secretions and the roles played by these secretory proteins in airway homeostasis are only recently being appreciated ${ }^{(9)}$.

The Clara cell protein is a $16 \mathrm{kDa}$ lung epithelium specific protein known for the vulnerability to different insults. Putative roles of $\mathrm{CC} 16$ include an antiinflammatory effect mediated by inhibition of phospholipase A2 and detoxification of xenobiotics. Recently, it was shown that CC 16 secreted in the respiratory tract diffuses passively across the bronchoalveolar-blood barrier into the serum. Therefore, CC 16 has been proposed to be a useful marker in evaluating the integrity of lung epithelial barrier (6).

On the other hand, it is now well accepted that an additional humoral immune defense involving the secretory immunoglobulin A (sIgA) predominant in mucosal secretions, prevents adherence and absorption of noxious bacteria] or viral agents. This humoral defense acts as a scavenger through the so-called "immune exclusion". This mechanism requires the expression of a specific receptor for polymeric IgA on the basolateral surface of epithelial cells, thus allows their active transport into the mucosal lumen ${ }^{(7)}$. This secretory immune system in close cooperation with the epithelial cells, probably acts in synergy with mucociliary clearance and constitutes the first line of defense of the proximal respiratory tract (10).

Accordingly, tills study was carried out in order to study the defense mecha- 
nisms of the respiratory tract against particulate air pollution in quarries. In addition, an attempt was made to evaluate the use of lung specific proteins as early, noninvasive biologic marker for respiratory injury and its validity over the traditional pulmonary function tests.

\section{Materials and Methods}

\section{Study Population:}

This work was carried out in silica quarries in Alexandria, El-Agamy District. The study population included 54 individuals divided into exposed and control groups. The exposed group consisted of 29 worker randomly selected frorn those individuals working in the cutting, carrying and packing of stones. An oral consent was obtained from included subjects. The workers were all male's with age ranging from 28 to 59 years. The duration of exposure to silica respirable dust ranged from 14 to 36 years. The total number of tobacco packs smoked in the number of years known as the smoking index (SI) was chosen as a rneasure of current tobacco consumption 11). As for the control group, a total of 25 individuals working as food sellers in some markets and as waiters in small coffee shops were chosen from places far from dusty areas, thus excluding the probability of silica dust exposure. The control population matched the exposed groups in age, sex, social factors and special habits.

\section{Clinical Assessment:}

Data collection included a detailed assessment questionnaire interviewing exposed and control groups about the exposure and its pattern. Thorough clinical examination was done for the individuals of both exposed and control groups included in the research for the diagnosis of bronchial asthma, chronic bronchitis and chronic obstructive pulmonary disease (COPD). Diagnosis of COPI) was based on history of chronic bronchitis associated with old reports of decreased FEVI/FVC\% below $70 \%$ after inhalation of short-acting bronchodilator as well as recently performed pulmonary function tests carried out in the current study (12).

\section{Spirometry:}

The spirometric measurements for all individuals were carried out around 3 hours from the beginning of the shift, as the assessment was not feasible, neither before nor after the shift work. The parameters obtained using a calibrated portable vitalograph included the forced expiratory volume in one second (FEV1\%); forced 
vital capacity (FVC\%); forced expiratory volume in one second in relation to forced vital capacity (FEVIIFVC01o); forced expiratory flow rate $25-75 \%$ (FEF25-75y) and the forced expiratory flow rate 7585\% (FEF75-N5\%). The American Thoracic Society standards for testing were followed and the best of 3 trials for all parameters was obtained. The volumes were recorded in liters and corrected for body temperature atmospheric pressure and saturation with water vapor (BTPS).

\section{Laboratory Investigations:}

A small sample of 5 nil venous blood was taken under complete aseptic conditions from all individuals. The sample was kept in a plain tube without anticoagulant for serum separation to determine the immunoglobulin A (sIgA) level in serum. Estimating the sIgA level was done using single radial immunodiffusion plates. Well diameters were read after 24 hours and the corresponding Igs concentration was determined by plotting against calibrators (31). Liver functions namely alanine transaminase (ALT) and aspartate transaminase (AST) as well as kidney function tests namely urea and Creatinine were estimated using Hitashi (911) autoanalyser. La Roche Germany supplied the kits and instruments.

\section{Clara Cell Protein (CC 16) Analysis:}

The concentration of Clara cell secretory protein 16 (CC16) in serum was determined by a sensitive immunoassay relying on the agglutination of latex particles. The assay uses the rabbit anti-protein I antibody from Dakopatts (Glostrup, Denmark) and as standard the protein purified in the laboratory. To avoid possible interference by complement, rheumatoid factor or chylomicrons, sera were pretreated by heating at $56 \mathrm{uC}$ for $30 \mathrm{~min}$ and by the addition of polyethylene glycol (16\%, vol/vol, 1/1) and trichloroacetic acid (10\%, vol/vol, 1/ 40). After overnight precipitation at $4 \mathrm{uC}$, the serum samples were centrifuged $(3,0006 \mathrm{~g}$ for $10 \mathrm{~min})$ and CC16 was determined in the supernatants. All samples were analysed in duplicate at two different dilutions. The validity and the analytical performances of the CC] 6 latex immunoassay (LIA) in different biological media have been reported previously $(14,15)$. The assay has a detection limit of $0.5 \mathrm{mg} /$ $\mathrm{L}$ and an average analytical recovery of 95\%, with the intra- and inter-assay coefficients of variation ranging from 5 to $10 \%$.

\section{Statistical Analysis.}

The mean and standard deviation (SD) were calculated. Unpaired student's t-test 
was used to evaluate the relation between the different indices and compare the two study groups. Pearson correlation coefficient was used to relate between age, duration of exposure, smoking index, levels of immunoglobulin A (sIgA) and clara cell protein (CC16) in serum, as well as the different parameters of pulmonary function tests. $\mathrm{P}$ value of $<0.05$ was considered significant.

\section{Results}

This study was carried out on a group of workers exposed to respirable and nonrespirable dust particles in stone quarrying. The control group was selected so as to match the exposed group in age, sex, social conditions and smoking habits. The mean \pm SD of age was $48.69 \pm 7.82$ year in the exposed group and $46.88 \pm 6.34$ year in the control group. As regards the smoking index, the mean \pm SD were 18.28 \pm 7.77 and $19.72 \pm 6.18$ among the exposed group $(n=29)$ and the control group $(n=25)$, respectively. The duration of exposure for the exposed population ranged from 14 to 36 years with a mean of 26.07 \pm 6.36 year.

The frequency distribution of the most important relevant clinical manifestations among the exposed workers and the control group were evaluated, data not pre- sented. According to the thorough occupational history and clinical examination, respiratory system affection in the form of harsh vesicular breathing (21 cases; $72.4 \%$ ) and chest wheezes (24 cases; $82.8 \%$ ) are commonly present among the exposed population compared to 3 cases $(12 \%)$ and 2 cases ( $8 \%)$ among the control group, respectively. Additionally, frequent asthmatic attacks were reported among 10 $(34.5 \%)$ of the exposed workers, whereas only $2(8 \%)$ of the unexposed workers complained of attacks of asthma. Chronic bronchitis, defined by presence of productive cough for three consecutive months for at least 2 years, was diagnosed in 22 (75.9\%) exposed worker in contrast to only $2(8 \%)$ among the control group. A total of 22 cases $(75.9 \%)$ suffering from COPD were detected amon the exposed population and only 92 cases (8\%) among the control group. No statistically significant difference was detected among both groups as regards the clinical data.

Estimation of clara cell protein (CC16) in the study population revealed marked elevation of the protein in the serum of exposed group with a mean of $149.61 \pm$ $22.64 \mathrm{pg} / \mathrm{ml}$, than among the control group $(107.08 \pm 12.18 \mathrm{pg} / \mathrm{ml})$. Similarly, the level of immunoglobulin A in serum (sIgA) was higher among exposed than control 
groups; mean values being $372.41 \pm$ $232.87 \mathrm{IU} / \mathrm{ml}$ and $143.76 \pm 83.53 \mathrm{IU} / \mathrm{ml}$, respectively. The difference in the levels of CC] 6 and sIgA between both groups proved to be statistically significant, $\mathrm{P}$ value $<0.05$. Evaluation of the liver and kidney functions was caff ied out to assess the deleterious effects of silica on both liver and kidney function. Among the liver functions, serum glutarnic-oxaloacetic transaminase (SGOT) and glutamicpyruvic transaminase (SGPT) enzymes were slightly elevated above normal, but no statistical difference was obtained between the exposed $(n=29)$ and control $(n=25)$ groups. Similarly, the kidney functions revealed no statistically significant difference between the groups (Table 1).

The pulmonary function tests were carried out for both exposed and control groups. The data obtained revealed no significant difference between the results of all parameters except for the forced expiratory flow rate $25-75 \%$ (FEF25-7.50 which showed a statistically significant difference between the groups. The mean values obtained were $55.79 \pm 21.85$ among the exposed group and $83.56 \pm 8.43$ for the control group (Table 2).

Further assessment of the relationships between the different variables in the study was done. Accordingly, a negative correla- tion was revealed for the effect of age versus both the pulmonary function tests and sIgA level, while, a positive correlation was detected versus the CC16 serum level. All associations were not statistically significant except for FEF25-75\% rate as the association proved to be highly significant ( $\mathrm{P}$ value $<0.005$ ). Additionally, a highly significant negative correlation was obtained between the effect of smoking (SI) and both CC 16 and FEVI/FVC. Studying the association between the duration of exposure to dust particles and different parameters showed a negative correlation that proved to be highly significant for FEF25-75\% rate but only significant for FEF75-85\% rate (Table 3).

The levels of serum clara cell protein and immunoglobulin A subsequently intercorrelated revealed a positive highly significant association in between the two parameters. As regards the relation between the Clara cell protein and pulmonary function parameters, a significant negative correlation was obtained for FVC and a positive correlation for FEVI. The IgA showed a significant negative correlation with FEVI/FVC and a highly significant correlation with FVC. Additionally, highly significant negative relations were revealed for both CC 16 and IgA versus the flow rates (Table 3 ). 
Table (1): Mean \pm SD of the results of Different Laboratory Investigations among the Group of Workers exposed to Silica Dust in Quarries $(n=29)$ and the Nonexposed Control Group $(\mathrm{n}=25)$.

\begin{tabular}{|c|c|c|c|c|c|}
\hline & & $\begin{array}{c}\text { Exposed } \\
\text { Group } \\
n=29\end{array}$ & $\begin{array}{l}\text { Control } \\
\text { Group } \\
\mathrm{n}=25\end{array}$ & t-test & (p-value) \\
\hline \multirow[t]{3}{*}{ Urea } & Range & $20.2-53.2$ & $20.2-43.7$ & & \\
\hline & Mean & 38.169 & 35.388 & 0.1522 & 0.773 \\
\hline & SD & 6.560 & 7.505 & & \\
\hline \multirow[t]{3}{*}{ Creatinine } & Range & $0.82-2.04$ & $0.7-1.9$ & & \\
\hline & Mean & 1.320 & 1.184 & 0.1736 & \\
\hline & SD & 0.375 & 0.346 & & \\
\hline \multirow[t]{3}{*}{ ALT } & Range & $5.7-56.3$ & $6.7-34.6$ & & \\
\hline & Mean & 26.910 & 19.78 & 0.0339 & $0.0001 *$ \\
\hline & SD & 14.079 & 8.959 & & \\
\hline \multirow[t]{3}{*}{ AST } & Range & $14-56.2$ & $13.8-43.7$ & & \\
\hline & Mean & 34.328 & 25.992 & 0.0079 & $0.0001 *$ \\
\hline & SD & 12.445 & 9.158 & & \\
\hline \multirow[t]{3}{*}{ CC16 } & Range & $98.7-196.2$ & $85.8-124.8$ & & \\
\hline & Mean & 149.614 & 107.084 & 2.500 & $0.0001 *$ \\
\hline & SD & 22.464 & 12.176 & & \\
\hline \multirow[t]{3}{*}{$\operatorname{sIg} \mathrm{A}$} & Range & $80-920$ & $56-451$ & & \\
\hline & Mean & 372.414 & 143.76 & 2.280 & $0.0001 *$ \\
\hline & SD & 232.865 & 83.531 & & \\
\hline
\end{tabular}

Urea (mg/dl); Creatinine (mg/dl); ALT: Alanine Transaminase (IU/L); AST: Aspatate Transaminase (IU/L);

CC16: Clara Cell Protein 16 (pg/ml); sIgA: serm Immunoglobulin A (IU/ml).

NS: Non-significant $\mathrm{P}>0.05 \quad *$ Significant $\mathrm{P}<0.05$ 
Table (2): Mean \pm SD of the results of Pulmonary Function Tests among the Group of Workers exposed to Silica Dust in Quarries $(n=29)$ and the Non-exposed Control Group $(\mathrm{n}=25)$.

\begin{tabular}{|c|c|c|c|c|c|}
\hline & & $\begin{array}{c}\text { Exposed } \\
\text { Group } \\
n=29\end{array}$ & $\begin{array}{l}\text { Control } \\
\text { Group } \\
\mathrm{n}=25\end{array}$ & $\begin{array}{l}\text { t-test } \\
0.0386\end{array}$ & $\begin{array}{l}\text { P value } \\
\text { N.S. }\end{array}$ \\
\hline $\mathrm{FVC} \%$ & Range & $39-98$ & $72-99$ & \multirow{3}{*}{0.0176} & \multirow[b]{3}{*}{ N.S. } \\
\hline FEV1\% & Mean & 76.379 & 85.120 & & \\
\hline FEV $1 / \mathrm{FVC} \%$ & $\mathrm{SD}$ & 19.301 & 7.661 & & \\
\hline FEF $25-75 \%$ & Range & $46-103$ & $65-96$ & 0.0218 & \multirow{3}{*}{ N.S. } \\
\hline \multirow[t]{2}{*}{ FEF75-85\% } & Mean & 88.862 & 81.360 & & \\
\hline & SD & 13.330 & 8.046 & 2.0378 & \\
\hline & Range & $42-98$ & $55-99$ & \multirow{3}{*}{1.2306} & \multirow[t]{3}{*}{$0.0467 *$} \\
\hline & Mean & 70.759 & 79.840 & & \\
\hline & SD & 14.111 & 14.019 & & \\
\hline & Range & 17 - 99 & $65-99$ & & \\
\hline & Mean & 55.789 & 83.560 & & \\
\hline & SD & 21.845 & 8.431 & & \\
\hline & Range & $18-99$ & $60-101$ & & \\
\hline & Mean & 53.966 & 80.240 & & \\
\hline & $\mathrm{SD}$ & 20.547 & 12.451 & & \\
\hline & & & & & \\
\hline & & & & & \\
\hline
\end{tabular}

FEV1\%: Forced Expiratory Volume in one second; FVC: Forced vital capacity;

FEV1/FVC: Forced Expiratory Volume in one second in relation to Forced vital capacity;

FEF25-75\%: Forced Expiratory Flow rate 25-75\%; FEF75-85\%: Forced Expiratory 


\section{Discussion}

The particulate matter (PM) emissions from quarries can cause adverse effects to neighboring communities and to the environment. Quarry dust generated comes from a number of different activities and sources including crushing and screening (50\%), haul roads and traffic (48\%) and to a lesser extent from blasting (2\%) (16). Bench and block cutting is a wet process, with minimal exposure to fine dust. Nevertheless, when mud dries on the quarry floor, workers are exposed to the inhalation of dust raised by wind and the transit of the vehicles (17).

It is only the very smallest particulate matter (PM2.5) which is only 1-2 pm that is transported into the alveoli and which actually leads to chronic health effects. With regard to particle size, a recent report calculates that only $28 \%$ of all dust generated in quarrying is respirable, most of the dust emitted is in the coarse size range, more than 2.5 RM 1181 . The risk of silicosis depends on the amount of quartz actually present in the dust and the diameter of free silica particles. In many work operations, the exposure level to respirable dust in Egypt can reach a daily average $400 \mathrm{Rg} / \mathrm{m}$ ' exceeding the Air Quality Limit Value $70 \mathrm{Rg} / \mathrm{m}^{\prime}$ for Egypt ${ }^{(19)}$. These high concentrations are observed near the areas of brick industries and quarries as well as crowded and traffic-congested roads (20).

Quarry workers are affected not only because of the dust content of crystalline silica, but also because of exposure to unfavorable macroclimatic conditions, and tobacco smoking (17). Yet, exposure to particulate air pollution is the major factor for increasing epithelial barrier permeability in the lung sending in chronic obstructive pulmonary diseases (COPD) (21).

In patients with severe COPD, secretory immunoglobulin $\mathrm{A}$ ( $\operatorname{sg} \mathrm{A})$-dependent immunity was found to be clearly impaired in the bronchi (14). The $\operatorname{sIgA}$ was thought to prevent chronic mucosal inflammation by down-regulating the proinflammatory processes mediated through monocytes and neutrophils (22), and by inhibiting adherence of antigens and microorganisms to the surface epithelium (7). Impairment of secretory immunity was found to provide a link between structural changes and inflammation (23).

Recently, in addition to the humoral sIgA-dependent immunity, a cellular type of immunity at the level of the epithelial barrier was considered. In small airways, the main epithelial cell type constituting 
the Clara cells were found to play an important physiological role in surfactant production, protection against environmental agents, in regulation of inflammatory and immune responses in the respiratory system and to be involved in lung homeostasis (24). Additionally, these epithelial cells are altered in diseases like asthma, Chronic Obstructive Pulmonary Diseases (COPD), cancers and several pulmonary pathological processes induced by various lung toxicants, thus secreting a specific type of protein. Clara cell protein (CC16) produced is a $15.8-\mathrm{kDa}$ protein secreted all along the tracheobronchial tree and especially in the terminal bronchioles where Clara cells are localized (25).

Being small in size, CC16 secreted in the distal air spaces, readily diffuses into the plasma. Several lines of evidence suggest that proteins cross the air-blood barrier paracellularly, through water-filled pores located at the junctional complexes linking epithelial and endothelial cells (26). CC16 entering the circulation distributes in the vascular and extravascular compartments and is rapidly eliminated by the kidney (27).

In this study, a group of workers exposed to respirable and non-respirable dust particles in stone quarrying were randomly selected. Occupational exposures to respirable silica-containing stone dust were found to be associated with the development of silicosis, lung cancer, pulmonary tuberculosis, and airway diseases. These exposures were also related to the development of autoimmune disorders, chronic renal disease and other adverse health effects (28).

In the current study, assessment of kidney and liver functions for the studied population showed no elevation or above normal levels for both urea and creatinine or for liver enzymes. However, earlier epiderniologic studies found statistically significant associations between the occupational exposure to PM 2.5 crystalline silica dust and several renal diseases or effects ranging from subclinical renal changes (29) to end-stage renal disease caused by glomerulonephritis ${ }^{(30)}$. Some case reports provided evidence of an immunologic injury by immune complex formation, and other reports pointed to a direct toxic effect of PM content of silica (31). In workers exposed to crystalline silica, hepatic changes and hepatocellular carcinoma have been identified, though the cause-effect relationship was not clear ${ }^{(32)}$.

Ambient air particulate pollution has been associated with adverse respiratory health effects in several studies (3). There 
is growing recognition that occupational exposures make a substantive contribution to adult-onset asthma, chronic bronchitis and other respiratory symptoms (33). Chronic obstructive pulmonary disease (COPD) is the major cause of morbidity and mortality among respiratory diseases. Physiologic investigations have indicated that small airways are a major site of increased resistance in COPD ${ }^{(34)}$. This disorder is characterized functionally by expiratory airflow limitation that is slowly progressive and mainly irreversible (4).

Although cigarette smoking is well documented as the major risk factor for COPD, only a minority (15 to $20 \%$ ) of heavy smokers will develop COPD ${ }^{(16)}$. In this study, the disease was diagnosed among $22(75.9 \%)$ of exposed workers compared to $2(8 \%)$ cases of the control group, and the difference was not statistically significant. The disease detected among the control group might have been attributed to cigarette smoke, as both cases were moderate smokers with smoking index 26 and 28 pack-year, respectively.

There is now growing evidence that airways obstruction (COPD) are caused by occupational exposures to PM2.5. Most of these workers started working in the field very early in life with mean value of expo- sure onset around $22.62 \pm 4.7$ years. In fact, age-related structural and functional changes in the lung have been previously described. Gas trapping increases with age as do airspace abnormalities and diameter, whereas lung compliance decreases in association with increased lung elastin content (35). Moreover, the internal surface area of the lung increases to a maximum of $80 \mathrm{~m} 2$ at the age of 20 years, but decreases by $2.7 \mathrm{~m} 2$ per decade thereafter [36], therefore the exposure in early adult life appeared to have more effect than later exposure (37).

The duration of exposure to dust particles in the current study that ranged from 14 to 36 years (mean value $26.1 \pm 6.4$ years) was associated with affection of 13 (44.8\%) cases from airflow obstruction and chronic obstructive pulmonary disease as diagnosed based on history and lung function tests ${ }^{(12)}$. Severe affection of the expiratory flow rates was correlating with the duration of exposure, in contrast to the other parameters which were not markedly if at all affected. Many studies with quantitative data on silica dust exposure reported statistically significant associations between loss of lung function and cumulative respirable dust exposure in workers [38]. Exposure to dust containing $0.09 \mathrm{mg} /$ 
m3 of crystalline silica at an average respirable concentration of $0.3 \mathrm{mg} / \mathrm{m} 3$ for 24 years was associated with loss of $236 \mathrm{ml}$ of FEV1. This loss was reported to be equivalent to about half of the estimated loss of FEV1 in a typical male who smoked one pack of cigarettes per day for 30 years $(552 \mathrm{ml}){ }^{(39)}$. No significant difference in smoking index (SI) was reported between both groups included in the present study, yet correlating the data among the whole study population showed a negative highly significant association of SI versus the FEV1/FVC. In fact, the combined effects of respirable dust exposure and smoking on the loss of FEV1 must be additive ${ }^{(40)}$.

Though lung function tests alone cannot diagnose any particular disease (41), yet they are an important part of the clinical evaluation of workers with occupational diseases. They are not diagnostic for silica exposure and silicosis (42). Currently there are no biological markers sufficiently sensitive to assess parenchymal lung health before functional abnormalities become apparent (43).

The use of induced sputum, nasal lavage, or the measurement of exhaled gases and breath condensate has been championed by many as providing less invasive methods for assessing pulmonary responses to air pollution challenges (44). In contrast, these methods have failed to demonstrate increased permeability in these studies. Tests based on the appearance of lung-specific proteins in serum following an airway insult have been proposed as a noninvasive and highly sensitive alternative to traditional markers of lung epithelial injury (45).

These proteins occur physiologically in small amounts in blood (46), being synthesized and secreted by the lung Clara cells. Other sex-linked sources such as the uterus and the prostate contribute nothing or very little to the serum CC16 concentrations (47). However, serum concentrations of $\mathrm{CC} 16$ show considerable variations in healthy subjects, the baseline concentrations reflect the number of Clara cells whereas the variation in time reflects the integrity of the lung epithelial barrier. This study was able to demonstrate a negative highly significant correlation between the level of CC16 and the smoking index. Tobacco smoke was able to induce reduction in CC16 serum levels due to decreased density of Clara cells in the lungs (48). Since Clara cells have a high content of xenobiotic metabolising enzymes, they are probably progressively destroyed by toxic 
metabolites of tobacco smoke generated via the cytochrome P450 system and might be involved in the progressive destruction of lung parenchyma ${ }^{(6)}$.

However, serum concentration of $\mathrm{CC} 16$ has been reported to increase slightly with aging ${ }^{(6)}$. In fact, a positive correlation was determined with age among the studied population but was nonsignificant. The Clara cell protein produced in large amounts into the lumen of the respiratory tract, a condition referred to as pneumoproteinaemia, cross the lung epithelial barrier into the vascular compartment through passive diffusion (43). Although the mechanism for the chronic increase in leakage is unknown, recent findings suggest that the changes are associated with repeated inflammatorymediated acute lung injury, increased oxidant load and depletion of antioxidants including glutathione ${ }^{(6)}$.

Indeed, their intravascular leakage increases in conditions characterized by pulmonary inflammation and/or pulmonary epithelial injury (46). Degranulation and consequent secretion of granule contents can be induced by inhaled pollutants [49] in several situations known to be associated with a disruption of the air-blood barrier, such as pulmonary fibrosis, interstitial lung diseases and in lung injury caused by lung irritants (45).

Airway irritation caused by particulate air pollution is known to impair lung function and induce airway inflammation (50). Previous studies have failed to find a clear association between lung function decrements and airway inflammation ${ }^{(51)}$. It has been suggested that lung function decrements are related to stimulation of airway C-fibres (52) and to the release of substance $\mathrm{P}$ from sensory nerves associated with epithelial injury. A significant reduction in FEV1 was observed immediately post-exposure, at this time serum $\mathrm{CC} 16$ concentrations were not increased suggesting that these two responses are not simply associated ${ }^{(53)}$.

On the contrary, studying the association between the pulmonary function tests and the level of CC16 revealed highly significant negative results with the expiratory flow rates but significant with functional vital capacity indicating the presence of a restriction element as a result of accumulating proteins. As for the other pulmonary function parameters, a positive correlation was obtained, proved to be significant with the FEV1, but non-significant with FEV1/ VC. In fact, previous epidemiological studies reported that subjects with chronic 
obstructive pulmonary disease have a significant reduction of CC16 in serum, pneumoproteinaemia inversely correlating with FEV1/VC (43), and that mid-expiratory flow rates are powerful predictors of mortality from $\mathrm{COPD}^{(54)}$.

However, the functional roles of Clara cell secretions that are induced by exposure to various environmental agents are poorly understood. Despite the paucity of information regarding biogenesis and packaging of secreted proteins from Clara cells, considerably more work has been performed investigating mechanisms of Clara cell secretion. A number of studies have demonstrated that secretion of granule contents by Clara cells is activated by either adrenergic or cholinergic agents (55). Clara cell secretory protein has been shown to interact with microsomal and plasma membranes through binding to an integral membrane protein ${ }^{(56)}$, and has been shown to bind other secreted proteins such as fibronectin (57). Lack of these interactions may result in alterations in the signaling events which contribute to the synchronization of protective responses, such as the degranulation of Clara cells and subsequent activation of epithelial regeneration ${ }^{(58)}$. As such, Clara cell protein has been ascribed an anti-inflammatory role in lung diseases ${ }^{(59)}$.

In chronic obstructive pulmonary disease, bronchial and parenchymal damage is thought to lead to defects in airflow and gas exchange. Despite important epithelial changes in the bronchi, only indirect data suggest a decreased production of epithelial-derived CC16 that is more striking in small than in large airways ${ }^{(60)}$. The decreased expression of $\mathrm{CC} 16$ is proved by the results of pulmonary function tests performed on the current studied population which revealed a highly significant inverse reduction of the expiratory flow rates 25 $75 \%$ and $75-85 \%$ with the CC16 concentrations. This finding is due to the relative preservation of $\mathrm{CC} 16$ expression in large airways as a result of goblet cell hyperplasia which is more intense in these airways (61). These studies indicate that modulation of Clara cell secretory function may play an important role in airway homeostasis and disease pathogenesis. Clara cell secretory protein has been described as a "multifunctional protein" and among these many postulated functions is most frequently quoted as being a potent regulator of the inflammatory response ${ }^{(62)}$.

The relationship of inflammatory and immune parameters to structural changes in the airways remains unclear. It is now 
well accepted that the secretory immunoglobulin A (SIgA), the predominant Ig isotype in mucosal secretions, prevents adherence and absorption of noxious agents, acting as a scavenger through so-called "immune exclusion". The IgA is produced by the mucosal subepithelial plasma cells in dimeric form which is actively transported across the airway epithelium by trans-cellular routing assumed by the polymeric immunoglobulin receptor (pIgR). At the apical pole of the airway epithelial cell, the IgA-pIgR complex is cleaved from the cell membrane to release the secretory $\operatorname{Ig} \mathrm{A}$, which is formed by dimeric $\operatorname{Ig} \mathrm{A}$ covalently bound to the extracellular part of the $\mathrm{pIgR}$, called the secretory component (SC) (7).

Estimation of the $\operatorname{sg} \mathrm{A}$ in serum of the study population revealed significant elevation not correlating with age, smoking index or the duration of exposure, but correlating positively and highly significantly with the level of CC16 in serum. Experimental studies revealed that the secretory immune system implies close cooperation between the submucosal immunoglobulinsecreting plasma cells and the epithelial cells, thus acting in synergy with the mucociliary clearance and constituting the first line of defense of the proximal respir- atory tract ${ }^{(63)}$. In addition to the positive correlation with $\mathrm{CC} 16$, a negative highly significant correlation between the $\operatorname{IgA}$ and expiratory flow rates as well as the FVC and FEV1/FVC was revealed. Related studies reported that deficiency of CC16 and altered expression of immunoglobulin A may be associated with global alterations in lung homeostasis with either direct or indirect effects on lung immunoregulation ${ }^{(63)}$.

Studies carried out recently proved that the expression of the $\mathrm{pIgR}$ is decreased in patients with mucosal diseases such as chronic inflammatory diseases of the airways caused by the exposure to air particulates. These results were strongly demonstrated in the bronchial epithelium of patients with severe COPD but not in smokers without COPD. Moreover, pIgR expression correlated with lung function tests of airway obstruction such as the forced expiratory volume in one second (FEV1). Therefore, the impairment of bronchial secretory immunity was suggested to play a role in COPD pathogenesis following exposure to low-dose endotoxin (64).

The $\operatorname{Ig} \mathrm{A}$ is therefore the main antibody isotype in mucosal secretions of the respiratory tract, thus contributing to frontline 
mechanisms of defense along with mucociliary clearance and innate epithelialderived factors. However, the role of IgA in chronic airway inflammation and whether it represents a consequence of the disease or is implicated as a driving factor of its development, playing a causative role and presumably related to intrinsic changes of bronchial epithelium is to be evaluated.

Nevertheless, the utility of epithelial cells and the secreted Clara cell protein 16 in serum that reliably reflects the leakage of the lung epithelial barrier to proteins, appear to be useful indices, integrating components of both cellular toxicity and epithelial barrier function. Therefore, the CC16 might be proposed a useful marker of airway and lung epithelial injury. Potentially, the concept of pneumoproteinaemia has the equivalent utility to that of monitoring proteinuria in kidney diseases, since the passage of proteins across the lung barrier is governed by similar structural and functional features as that of glomerular filtration.

Consequently, the use of different biomarkers, produced by distinct regions of the respiratory tract, may allow evaluation of present and past exposures to toxins, detection of early defects, identification of susceptible individuals and the derivation of acceptable exposure levels, thus helping establish causal associations between effects and putative toxic agents. However, the application of serum $\mathrm{CC} 16$ as a noninvasive biomarker for air pollution-induced lung epithelial injury should be considered with caution being related to potential diurnal variation in serum concentrations, the impact of background exposures on $\mathrm{CC} 16$ responses and the large inter-subject variation in baseline concentrations. Larger studies are, therefore, needed to determine normal variance before utility of pneumoproteinaemia can be fully exploited. Despite these limitations, the strength of the data further underpins potential utility of pneumoproteins as markers of parenchymal lung health.

Results obtained from this study underlines the importance of carefully standardized studies in air pollution epidemiology and the utility of efforts to decrease concentration of ambient air pollutants as harmful health effects are observed even at low concentrations. Accordingly, a prevention plan for the protection of workers in quarries should be addressed.

Periodical inspections of the workplace and the exposed workers are needed with the subsequent removal of affected 
personnel. Collective and individual preventive measures should be adopted, together with the implementation of medical surveillance programs that provide clinical evaluation at least once a year. In addition to health history and physical examination, specific tests are to be carried out every one or two years in the form of pulmonary function tests and chest radiography in quarrymen exposed to dust and estimation of $\mathrm{CC} 16$ for the early detection of lung irritation in an attempt to detect lung affection before the disease is irreversible.

To reduce exposure to inhalable dust, prevention measures should include scrupulous wet cutting, cleaning of the work area by clearing away the mud by hand or with a mini-loader, and wetting the quarry floor and the access roads, especially in the drier seasons. During these operations, workers have to wear adequate personal protective equipment to protect respiratory airways and lungs. Underground sites have to be equipped with ventilation systems, adjustable according to the advancement of the exploitation in addition to increase in the natural ventilation by adequately widening the emergency exits or by creating special openings.

\section{References}

1. Zaidi A. (2005): Silent victims of silicosis. Indian Nat. Mag. 22(22):22-4.

2. Environmental Protection Agency EPA (2006): National ambient air quality standards for particulate matter. Federal Register 71(200):6114461233.

3. Brunekreef B. and Holgate S.T. (2002): Air pollution and health. Lancet 360:1233-42.

4. American Thoracic Society (1986): Standards for the diagnosis and care of patients with chronic obstructive pulmonary disease (COPD) and asthma. Am. Rev. Respir. Dis. 136:225-44.

5. Committee of the Environmental and Occupational Health Assembly of the American Thoracic Society (1996): Health effects of outdoor air pollution. Am. J. Respir. Crit. Care Med. 153:350.

6. Robin M., Dong P. and Hermans C. (2002): Serum levels of CC16, SP-A and SP-B reflect tobacco-smoke exposure in asymptomatic subjects. Eur. Respir. J. 20:1152-61.

7. Brandtzaeg P., Jahnsen F.L. and Farstad I.N. (1996): Immune functions and immunopathology of the mucosa of upper respiratory pathways. Acta Otolaryngol. 116:149-59.

8. Clara M. (1937): Zur Histobiologie des Bronchialepithels. Z. Mikrosk. Anat. Forsch. 4:321-47.

9. Singh G. and Katyal S.L. (1997): Clara cells and Clara cell $10 \mathrm{kD}$ protein (CC10). Am. J. Respir. Cell Mol. Biol. 17:141-3.

10. Underdown B.J. and Schiff J.M. (1986): Immunoglobulin A: strategic defence at the mucosal 
surface. Annu. Rev. Immunol. 4:389-417.

11. Lange P., Nyboe J., Appleyard M., Jensen G. and Schnohr P. (1990): Ventilatory function and chronic mucus hypersecretion as predictors of death from lung cancer. Am. Rev. Respir. Dis. 141:613-5.

12. Yamaguchi K. (2007): COPD: criteria for diagnosis and classification of disease severity. Nippon Rinsho. 65(4):657-63.

13. Louis M., Bain J. and Bates I. (2001): Louis practical hematology, 9th edition. Hartcourt publisher limited 442-3.

14. Bernard A., Marchandise F.X., Depelchin S., Lauwerys R., and Sibille Y. (1992): Clara cell protein in serum and bronchoalveolar lavage. Eur. Respir. J. 5: 1231-8.

15. Bernard A., Lauwerys R., Noel A., Vandeleene B. and Lambert A. (1991): Determination by latex immunoassay of protein 1 in normal and pathological urine. Clin. Chim. Acta 201:23145.

16. European Respiratory Society (1995): Consensus statement: optimal assesment and management of chronic obstructive pulmonary disease (COPD). Eur. Respir. J. 8:1398-420.

17. Angotzi G., Bramanti L., Tavarini D., Gragnani M., Cassiodoro L., Moriconi L., Saccardi P., Pinto I., Stacchini N. and Bovenzi M. (2005): World at work: Marble quarrying in Tuscany. Occup. Environ. Med 62:417-21.

18. Occupational Safety and Health Administration OSHA (2003): Respiratory health and silica dust levels in the extractive industry. Occupational health report series 8:2003.

19. Japan International Cooperation Agency JICA (2002): The JICA country profile on environment, Egypt, 2:22.

20. American Conference of Governmental Industrial Hygienists (2004): Threshold limit values and biological exposure indices. Cincinnati, $\mathrm{OH}$.

21. Timonen K.L., Hoek G., Heinrich J., Bernard A., Brunekreef B., de Hartog J., Hämeri K., Ibald-Mulli A., Mirme A., Peters A., Tiittanen P., Kreyling W.G. and Pekkanen J. (2004): Daily variation in fine and ultrafine particulate air pollution and urinary concentrations of lung Clara cell protein $\mathrm{CC} 16$. Occup. Environ. Med. 61:908-14.

22. Wolf H.M., Vogel E., Fischer M.B., Rengs H., Schwarz H.P. and Eibl M.M. (1994): Inhibition of receptor-dependent and receptor-independent generation of the repiratory burst in human neutrophils and monocytes by human serum $\operatorname{IgA}$. Pediatr. Res. 36:235-43.

23. Culpitt S.V., Maziak W., Loukidis S., Nightingale J.A., Matthews J.L. and Barnes P.J. (1999): Effect of high dose inhaled steroids on cells, cytokines, and proteases in induced sputum in chronic obstructive pulmonary disease. Am. J. Respir. Crit. Care Med. 160:1635-9.

24. Petrek M., Hermans C., Kolek V., Fialova J. and Bernard A. (2002): Clara cell protein (CC16) in serum and bronchoalveolar lavage fluid of subjects exposed to asbestos. Biomarkers 7(1):5867. 
25. Bertin G., Poujeol C., Rubera I., Poujeol P. and Tauc M. (2005): In vivo Cre/loxP mediated recombination in mouse Clara cells. Transgenic Res. 14(5):645-54.

26. Schneeberger E.E. and Lynch R.D. (1996): Airway and alveolar epithelial cell junctions. In: Crystal R.G., West J.B., Weibel E.R. and Barnes P.J., eds. The Lung Scientific Foundations. 2nd ed. Philadelphia-New-York, Lippincott-Raven, pp. 505-515.

27. Doyle I.R., Hermans C., Bernard A., Nicholas T.E. and Bersten A.D. (1998): Clearance of Clara cell secretory protein $(\mathrm{CC} 16)$ and surfactant proteins $\mathrm{A}$ and $\mathrm{B}$ from blood in acute respiratory failure. Am. J. Respir. Crit. Care Med. 158:1528-35.

28. Calvert G.M., Steenland K. and Palu S. (1997): End-stage renal disease among silica-exposed gold miners: A new method for assessing incidence among epidemiologic cohorts. J. Am. Med. Assoc. 277(15):1219-23.

29. Hotz P., Gonzalez-Lorenzo J., Siles E., Trujillano G., Lauwerys R. and Bernard A. (1995): Subclinical signs of kidney dysfunction following short exposure to silica in the absence of silicosis. Nephron 70:438-42.

30. Calvert G.M. and Steenland K. (1997): Occupational exposure to silica and end-stage renal disease. J. Am. Med. Assoc. 278(7):5-47.

31. Wilke R.A. (1997): Occupational exposure to silica and end-stage renal disease. J. Am. Med. Assoc. 278(7):546-7.

32. Oswald P., Filippi de la Palavesa M.M., Uhl G.,
Ghnassia J.P., Doffoel M. and Dietemann J.L. (1995): Silicose hepatosplenique. J. Radiol. 76 (8):513-6.

33. LeVan D., Koh W., Lee H., Koh D., Yu M. and Stephanie J. (2006): Vapor, Dust and Smoke Exposure in relation to adult-onset asthma and chronic respiratory symptoms: The Singapore Chinese Health Study. Am. J. Epidemiol. 163 (12):1118-28.

34. Hogg J., Macklem P.T. and Thurlbeck W.M. (1968): Site and nature of airway obstruction in chronic obstructive lung disease. N. Engl. J. Med. 178:1355-69.

35. Lee K.W., Chung S.Y., Yang I., Lee Y., Ko E.Y. and Park M.J. (2000): Correlation of aging and smoking with air trapping at thin-section CT of the lung in asymptomatic subjects. Radiology 214:831-6.

36. Burge P.S. (1994): Occupation and chronic obstructive pulmonary disease (COPD). Eur. Respir. J. 7:1032-4.

37. Soejima K., Yamaguchi K. and Kohda E. (2000): Longitudinal follow-up study of smoking-induced lung density changes by highresolution computed tomography. Am. J. Respir. Crit. Care Med. 161:1264-73.

38. Oxman A.D., Muir D.C., Shannon H.S., Stock S.R., Hnizdo E. and Lange H.J. (1993): Occupational dust exposure and chronic obstructive pulmonary disease. A systematic overview of the evidence. Am. Rev. Respir. Dis. 148: 38-8.

39. Dockery D.W., Speizer F.E., Ferris B.G., Ware J.H., Louis T.A. and Spiro A. (1988): Cumula- 
tive and reversible effects of lifetime smoking on simple tests of lung function in adults. Am. Rev. Respir. Dis. 137:286-92.

40. Hnizdo E. (1992): Loss of lung function associated with exposure to silica dust and with smoking, and its relation to disability and mortality in South African gold miners. Br. J. Ind. Med. 49:472-9.

41. Parkes W.R. (1994): Chronic bronchitis, airflow obstruction and emphysema. In: Parkes W.R. Occupational lung disorders. 3rd ed. London: Butterworth Heinemann, Ltd., pp. 222-37.

42. Wagner G.R. (1997): Occupational medicine: Asbestosis and silicosis. Lancet 349:1311-5.

43. Hermans C. and Bernard A. (1999): Lung epithelium-specific proteins. Characteristics and potential applications as markers. State-of-theart. Am. J. Respir. Crit. Care Med. 159:646-78.

44. Montuschi P., Nightingale J.A., Kharitonov S.A. and Barnes P.J. (2002): Ozone-induced increase in exhaled 8-isoprostane in healthy subjects is resistant to inhaled budesonide. Free Radic. Biol. Med. 33:1403-8.

45. Bernard A., Carbonnelle S., Nickmilder M. and de Burbure C. (2005): Non-invasive biomarkers of pulmonary damage and inflammation: Application to children exposed to ozone and trichloramine. Toxicol. Appl. Pharmacol. 206(2):18590.

46. Doyle I.R., Nicholas T.E. and Bersten A.D. (1997): Surfactant proteins (SP-A \& SP-B) in plasma in critically ill patients with respiratory disease. Am. J. Respir. Crit. Care Med.
156:1217-29.

47. Hagen G., Wolf M., Katyal S.L., Singh G., Beato M. and Suske G. (1990): Tissue-specific expression, hormonal regulation and 5'flanking gene region of the rat Clara cell $10 \mathrm{kDa}$ protein comparison to rabbit uteroglobin. Nucleic Acids Res. 18:2939-46.

48. Shijubo N., Honda Y. and Itoh Y. (1998): BAL surfactant protein A and Clara cell 10-kDa protein levels in healthy subjects. Lung 176:257-65.

49. Ooi H., Arakawa M. and Ozawa H. (1994): A morphological study of acute respiratory tract lesions in a lipopolysaccharide instilled rat model. Arch. Hist. Cytol. 57:87-105.

50. Lagerkvist B.J., Bernard A., Blomberg A., Bergstrom E., Forsberg B., Holmstrom K., Karp K., Lundstrom N.G., Segerstedt B., Svensson M. and Nordberg G. (2004): Pulmonary epithelial integrity in children: relationship to ambient ozone exposure and swimming pool attendance. Environ. Health Perspect. 112(17):1768-71.

51. Blomberg A., Mudway I.S. and Nordenha C. (1999): Ozone-induced lung function decrements do not correlate with early airway inflammatory or antioxidant responses. Eur. Respir. J. 13:1418-28.

52. Hazucha M.J., Bates D.V. and Bromberg P.A. (1989): Mechanism of action of ozone on the human lung. J. Appl. Physiol. 67:1535-41.

53. Krishna M.T., Springall D. and Meng Q.H. (1997): Effects of ozone on epithelium and sensory nerves in the bronchial mucosa of healthy humans. Am. J. Respir. Crit. Care Med. 
156:943-50.

54. Thomason M.J. and Strachan D.P. (2000): Which spirometry indices best predict subsequent death from chronic obstructive pulmonary disease. Thorax 55(9):785-8.

55. Massaro G.D., Fischman C.M., Chiang M.J., Amado C. and Massaro D. (1981): Regulation of secretion in Clara cells: studies using the isolated perfused rat lung. J. Clin. Invest. 67:34551.

56. Kundu G.C., Mantile G., Miele L., CordellaMiele E. and Mukherjee A.B. (1996): Recombinant human uteroglobin suppresses cellular invasiveness via a novel class of high-affinity cell surface binding site. Proc. Natl. Acad. Sci. USA 93:2915-9.

57. Zhang Z., Kundu G.C., Yuan C.J., Ward J.M., Lee E.J., DeMayo F., Wesphal H. and Mukherjee A.B. (1997): Severe fibronectin-deposit renal glomerular disease in mice lacking uteroglobin. Science 276:1408-12.

58. Stripp B.R., Reynolds S.D., Boe I.M., Lund J., Power J.H., Coppens J.T., Wong V., Reynolds P.R. and Plopper C.G. (2002): Clara cell secretory protein deficiency alters clara cell secretory apparatus and the protein composition of airway lining fluid. Am. J. Respir. Cell Mol. Biol. 27:170-8.

59. Ye Q., Fujita M., Ouchi H., Inoshima I., Maeyama T., Kuwano K., Horiuchi Y., Hara N. and Nakanishi Y. (2004): Serum CC-10 in inflammatory lung diseases. Resp. 71(5):505-10.
60. Pilette C., Godding V., Kiss R., Delos M., Verbeken E., Decaestecker C., De Paepe K., Vaerman J., Decramer M. and Sibille Y. (2001): Reduced epithelial expression of secretory component in small airways correlates with airflow obstruction in chronic obstructive pulmonary disease. Am. J. Respir. Crit. Care Med. $163: 185-94$

61. Boers J.E., Ambergen A.W. and Thunnissen F.B.J.M. (1999): Number and proliferation of Clara cells in normal human airway epithelium. Am. J. Respir. Crit. Care Med. 159:1585-91.

62. Mukherjee A.B., Kundu G.C., Mantile-Selvaggi G., Yuan C.J., Mandal A.K., Chattopadhyay S., Zheng F., Pattabiraman N. and Zhang Z. (1999): Uteroglobin: a novel cytokine. Cell. Mol. Life Sci. 55:771-87.

63. Di Stefano A., Capelli A., Lusuardi M., Balbo P., Vecchio C., Maestrelli P., Mapp C.E., Fabbri L.M., Donner C.F. and Saetta M. (1998): Severity of airflow limitation is associated with severity of airflow inflammation in smokers. Am. J. Respir. Crit. Care Med. 158:1277-85.

64. Pilette C., Detry B., Guisset A. and Sibille Y. (2006): Dual effect of neutrophils on secretory component production by human bronchial epithelial cells. Eur. Respir. Rev. 15:175-6. 
Table-2: Chi-square test (Number and percentage) of persons having and not having recurrent infections, sensory \& motor manifestations, cranial nerve involvement, manifestations of increased intracranial tension and impotence in group I and II as well as their statistical significance.

\begin{tabular}{|l|c|c|c|c|}
\hline Variable & Group & $\begin{array}{c}\text { Number \& Per- } \\
\text { centage of persons } \\
\text { having }\end{array}$ & $\begin{array}{c}\text { Number \& Per- } \\
\text { centage of persons } \\
\text { not having }\end{array}$ & $\begin{array}{c}\text { Statistical } \\
\text { significance } \\
\text { (p-value) }\end{array}$ \\
\hline Recurrent infec- & Group I & $-(0 \%)$ & $20(100 \%)$ & $0.0001^{*}$ \\
tions & Group II & $14(63.64 \%)$ & $8(36.36 \%)$ & \\
\hline Sensory affection & Group I & $-(0 \%)$ & $20(100 \%)$ & 0.139 \\
& Group II & $8(36.36 \%)$ & $14(63.64 \%)$ & \\
\hline Motor affection & Group I & $-(0 \%)$ & $20(100 \%)$ & $0.0001^{*}$ \\
Cranial nerve af- & Group I & $-(0 \%)$ & $20(100 \%)$ & $0.037 *$ \\
fection & Group II & $6(27.27 \%)$ & $16(72.73 \%)$ & \\
\hline increased intracra- & Group I & $-(0 \%)$ & $20(100 \%)$ & $0.0001^{*}$ \\
nial tension & Group II & $14(63.64 \%)$ & $8(36.36 \%)$ & \\
\hline Impotence & Group I & $-(0 \%)$ & $20(100 \%)$ & $0.037 *$ \\
& Group II & $6(27.27 \%)$ & $16(72.73 \%)$ & \\
\hline
\end{tabular}

$*=$ significant difference 


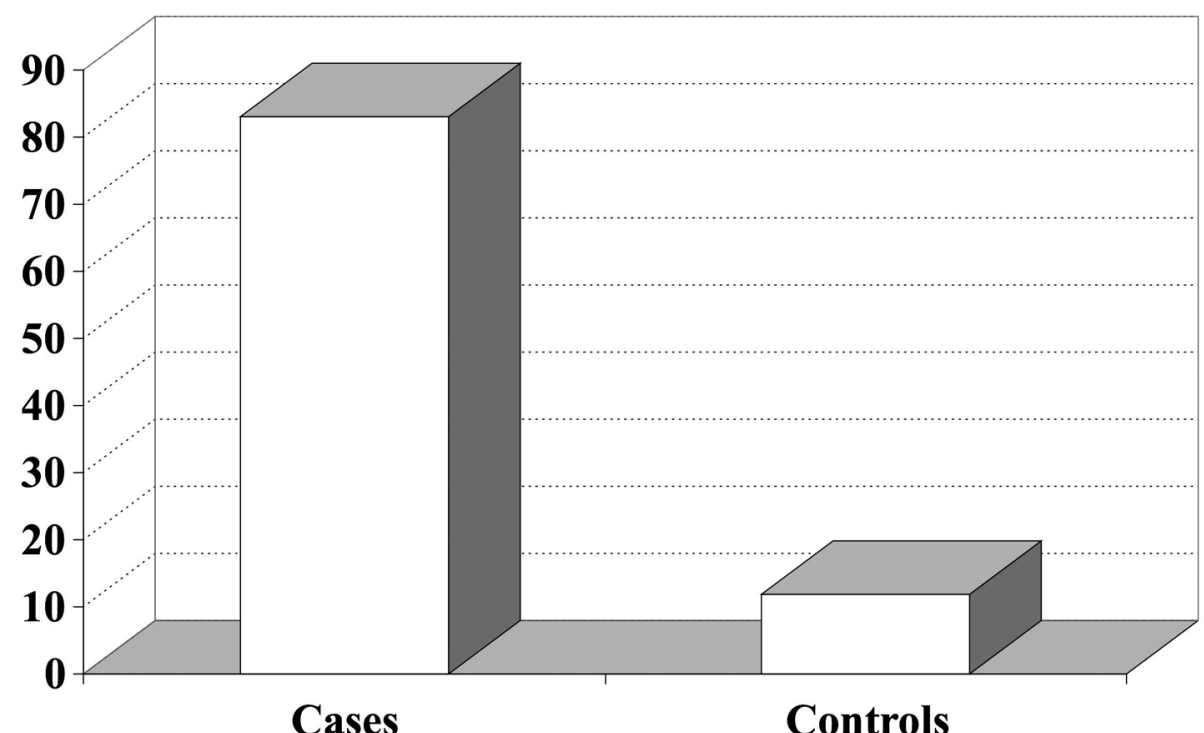

Figure (1): Mean values of blood lead ( $\mu \mathrm{g} / \mathrm{dl})$ in cases and controls.

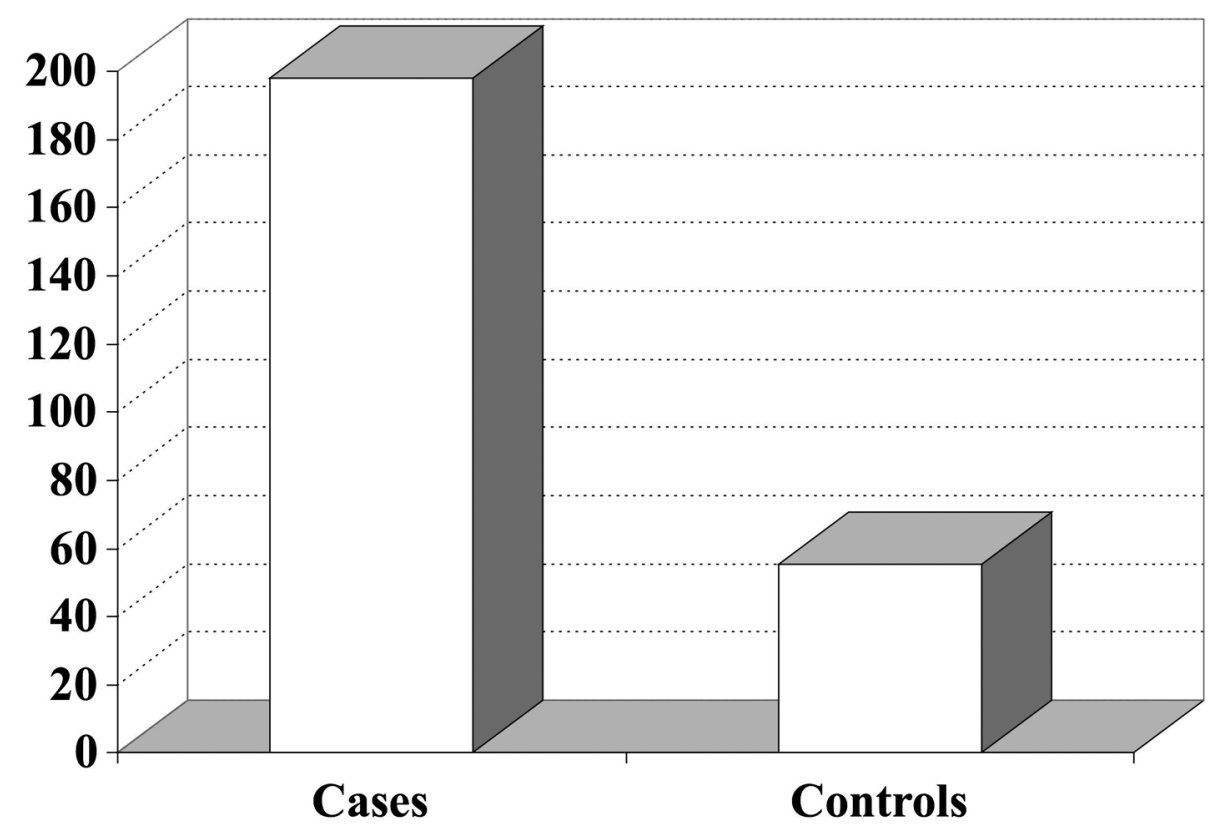

Figure (2): Mean values of serum MMP ( $\mu \mathrm{g} / \mathrm{ml})$ in cases and controls. 


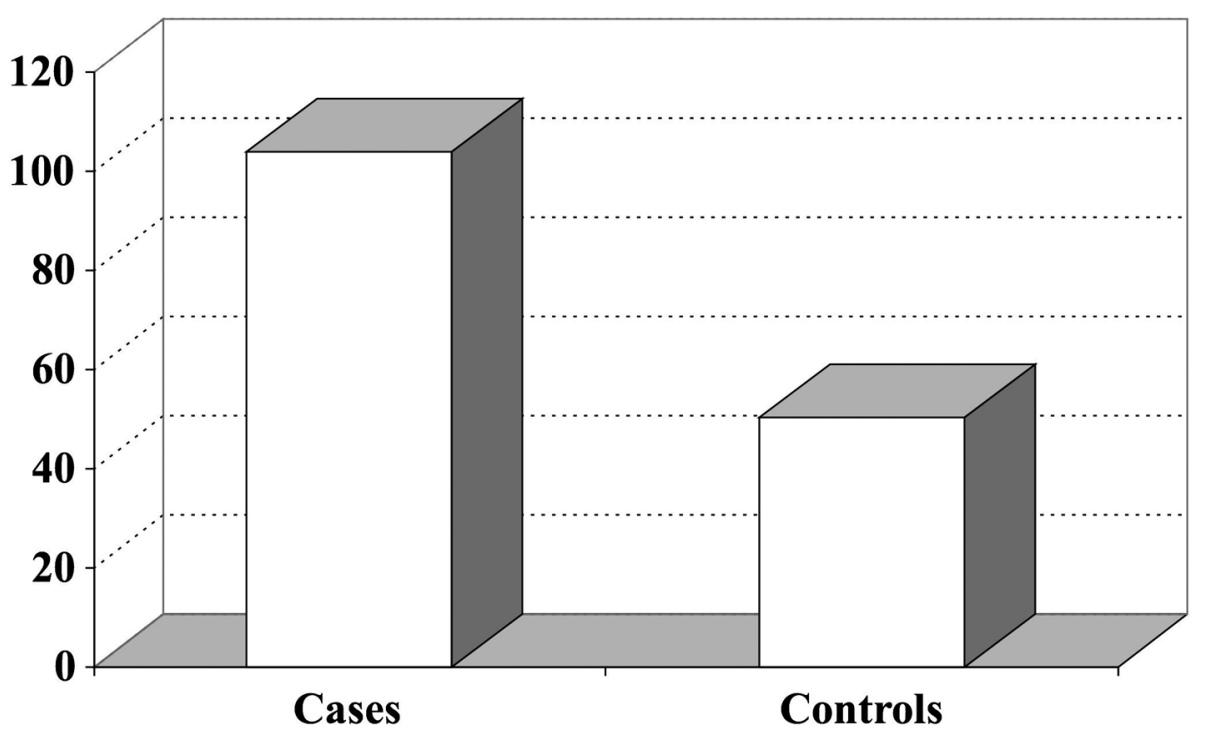

Figure (3): Mean values of serum TNF $\alpha$ (pg/dl) in cases and controls.

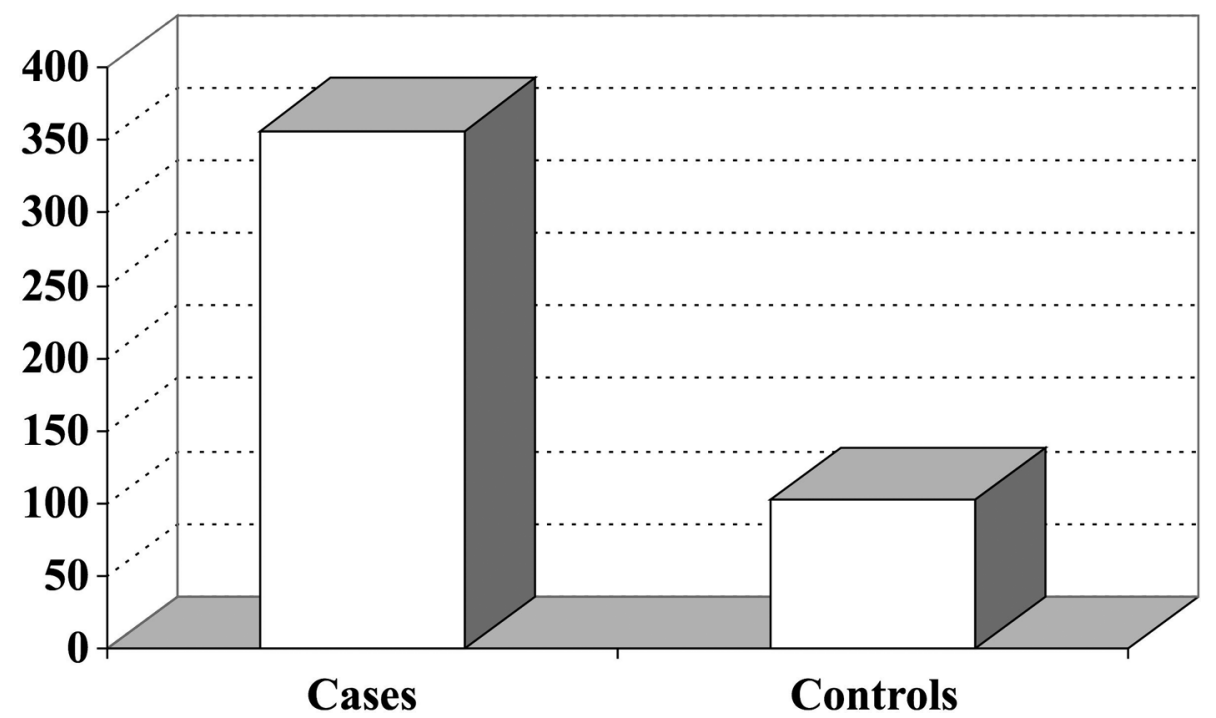

Figure (4): Mean values of serum IL1 (ng/dl) in cases and controls. 